\title{
Efek Hepatoprotektif Tanaman Obat
}

\author{
Christesa Y. Palawe, ${ }^{1}$ Carla F. Kairupan, ${ }^{2}$ Poppy M. Lintong ${ }^{2}$
}

\author{
${ }^{1}$ Program Studi Pendidikan Dokter Fakultas Kedokteran Universitas Sam Ratulangi, Manado, \\ Indonesia \\ ${ }^{2}$ Bagian Patologi Anatomi Fakultas Kedokteran Universitas Sam Ratulangi, Manado, Indonesia \\ Email: christesapalawe2007@gmail.com
}

\begin{abstract}
Medicinal plant that contain antioxidants is an alternative therapeutic option for liver disorders. This study was aimed to review the hepatoprotective effects of medicinal plants. This was a literature review study using PubMed, Google Scholar and Clinical Key. The results showed 10 hepatoprotective medicinal plants, as follows: soursop leaves, yellow bamboo shoots, moringa leaves, green betel leaves, libo fruit, kenikir, neem leaves, bitter bean seeds, black cumin, and solo garlic. All of them showed hepatoprotective activities based on the results of the tests, using biochemical and histopathological parameters. Soursop leaves could increase SOD level and reduce MDA level; yellow bamboo shoots were demonstrated to maintain SGPT activities and bilirubin level; moringa leaves have been associated with the reduction of MDA, SGOT, and SGPT levels; green betel leaves were able to reduce SGOT and SGPT levels and improve liver centrolobular necrosis; libo fruit was able to lower SGPT level; kenikir and bitter bean seeds were shown to reduce SGOT and SGPT levels; neem leaves were associated with the reduction of ALT level and protection against liver cell damage; black cumin was found to reduce fat degeneration; solo garlic could reduce MDA, SGPT, and SGOT levels, and maintain SOD level. In conclusion, the 10 hepatoprotective medicinal plants have the ability to increase SOD levels, reduce SGOT, SGPT and MDA levels, maintain bilirubin levels, regenerate centrilobular necrosis of the liver, and reduce fat degeneration of the liver. Solo garlic shows the largest amount of hepatoprotective activities, followed by yellow bamboo shoots, green betel leaves and libo fruit.
\end{abstract}

Keywords: medicinal plants, hepatoprotector effect

\begin{abstract}
Abstrak: Pengobatan menggunakan tanaman obat yang mengandung antioksidan merupakan pilihan terapi alternatif untuk gangguan pada hati. Penelitian ini bertujuan untuk menelaah efek hepatoprotektif tanaman obat. Jenis penelitian ialah literature review dengan menggunakan PubMed, Google Scholar dan Clinical Key. Hasil penelitian mendapatkan 10 tanaman obat hepatoprotektor yaitu daun sirsak, rebung bambu kuning, daun kelor, daun sirih hijau, buah libo, kenikir, daun mimba, biji petai, jintan hitam, dan bawang lanang. Tanaman-tanaman obat tersebut memiliki aktivitas hepatoprotektif berdasarkan pengujian dengan parameter biokimia dan histopatologi. Daun sirsak dapat meningkatkan kadar SOD dan menurunkan kadar MDA; rebung bambu kuning dapat mempertahankan aktivitas SGPT dan kadar bilirubin; daun kelor menurunkan kadar MDA, SGOT, dan SGPT; daun sirih hijau menurunkan kadar SGOT dan SGPT, serta memperbaiki nekrosis sentrolobuler hati; buah libo menurunkan kadar SGPT; kenikir dan biji petai menurunkan kadar SGOT dan SGPT; daun mimba menurunkan kadar SGPT dan memiliki daya proteksi terhadap kerusakan sel hati; jintan hitam dapat mengurangi degenerasi lemak; bawang lanang menekan peningkatan kadar MDA, SGPT, SGOT dan mempertahankan kadar SOD. Simpulan penelitian ini Kesepuluh tanaman obat hepatoprotektor tersebut memiliki kemampuan dalam meningkatkan kadar SOD, menurunkan kadar SGOT, SGPT dan MDA, mempertahankan kadar bilirubin, memperbaiki nekrosis sentrolobuler hati, dan mengurangi degenerasi lemak hati. Bawang lanang menunjukkan aktivitas hepatoprotektor terbesar, diikuti rebung bambu kuning, daun sirih hijau, dan buah libo.
\end{abstract}

Kata kunci: tanaman obat, efek hepatoprotektor 


\section{PENDAHULUAN}

Hati merupakan organ terbesar dalam tubuh setelah kulit yang memegang peranan penting untuk mempertahankan hidup dan berperan pada hampir setiap fungsi metabolisme tubuh. Oleh karena itu organ ini sangat rentan terhadap jejas sampah metabolit, zat toksik, dan jejas yang disebabkan oleh gangguan sirkulasi. ${ }^{1}$ Senyawa xenobiotik, yaitu senyawa-senyawa asing yang tidak dibutuhkan tubuh, akan mengalami proses metabolisme di hati yang menghasilkan produk sampingan berupa senyawa hidroksi yang merupakan radikal bebas. ${ }^{2}$ Hati memiliki kemampuan untuk beregenerasi dengan cepat, namun berbagai kondisi misalnya hepatitis, kebiasaan mengonsumsi alkohol, penggunaan obat-obatan jangka panjang, dan bahkan penyakit hati berlemak non-alkohol, dapat menyebabkan cedera terus-menerus pada hati dan memengaruhi efektivitas regeneratif hepatosit. Pada akhirnya, terbentuk jaringan parut, terjadi apoptosis, dan sirosis yang parah. ${ }^{3}$

Pengobatan menggunakan tanaman obat yang mengandung antioksidan merupakan pilihan terapi alternatif untuk gangguan pada hati. Selain karena efek terapeutiknya yang terbukti dan efektif, berbagai tanaman obat mudah didapat dan hemat biaya, serta ramah lingkungan. ${ }^{4}$ World Health Organization (WHO) telah merekomendasikan penggunaan obat tradisional dalam pemeliharaan kesehatan, pencegahan, dan pengobatan berbagai penyakit. Selain itu, WHO juga mendukung upaya dalam peningkatan mutu, keamanan dan juga khasiat obat tradisional. ${ }^{5}$ Berdasarkan Peraturan Badan Pengawas Obat dan Makanan Nomor 32 Tahun 2019 tentang Persyaratan Keamanan dan Mutu Obat Tradisional, obat herbal terstandar telah terbukti keamanan dan khasiatnya secara ilmiah dengan uji praklinik. Dengan demikian, penggunaan tanaman obat bermanfaat bagi kesehatan jika digunakan dengan dosis yang tepat. ${ }^{6}$

Peraturan Menteri Kesehatan Republik Indonesia Nomor 6 tahun 2016 tentang formularium obat herbal asli Indonesia membahas mengenai tanaman obat dan beragam manfaatnya bagi kesehatan. Dalam formularium tersebut dijelaskan bahwa kunyit (Curcuma domestica Val.), temulawak (Curcuma xanthorrhiza Roxb.), meniran (Phylanthus niruri Val.) dan paliasa (Kleinhovia hospital Folium Linn.) merupakan tanaman obat hepatoprotektor yang telah distandardisasi dan terbukti aman secara ilmiah/praklinik. ${ }^{7}$ Selain keempat tanaman obat tersebut, masih banyak tanaman obat yang memiliki potensi sebagai hepatoprotektor di Indonesia. Oleh karena itu, penulis tertarik melakukan penelitian dalam bentuk literature review mengenai tanaman obat hepatoprotektor dan efeknya pada hati. Tujuan penelitian ini ialah untuk menelaah efek hepatoprotektif tanaman obat sehingga dapat menambah pengetahuan mengenai tanaman obat yang bersifat hepatoprotektor sebagai obat alternatif untuk penyakit hati.

\section{METODE PENELITIAN}

Penelitian ini merupakan suatu literature review. Data yang digunakan berupa hasil penelitian yang dipublikasikan dalam jurnal ilmiah nasional maupun internasional. Terdapat tiga database untuk pencarian jurnal yaitu PubMed, GoogleScholar dan ClinicalKey. Kata kunci yang digunakan dalam pencarian artikel untuk PubMed dan ClinicalKey yaitu medicinal plants AND hepatoprotector effect, sedangkan untuk GoogleScholar menggunakan kata kunci tanaman obat $A N D$ efek hepatoprotektor.

\section{HASIL PENELITIAN}

Berdasarkan pencarian literatur, ditemukan sebanyak 1.068 artikel yang sesuai dengan kata kunci tersebut. Hasil pencarian yang sudah didapatkan kemudian dilakukan skrining untuk artikel yang dapat diakses berdasarkan rentang waktu dari tahun 20152020 dan didapatkan 570 artikel. Selanjutnya dilakukan skrining berdasarkan kriteria judul yang sesuai dengan topik penelitian dan didapatkan 150 artikel. Tahap berikutnya ialah skrining abstrak dan fulltext dan didapatkan 10 artikel, sehingga dilakukan kajian terhadap 10 artikel fulltext. Strategi yang digunakan untuk mencari artikel ialah PICOS framework yang terdiri dari 
population/problem, intervention, comparation, outcome, dan study design (Tabel 1).

Setelah melalui tahap seleksi studi didapatkan 10 literatur yang memenuhi kriteria inklusi dan ekslusi dengan desain penelitian experimental study, seperti yang disajikan pada tabel 2. Berdasarkan sepuluh literatur yang ditelaah, peneliti membuat tabel perbandingan untuk memaparkan populasi penelitian dan pembagian kelompok perlakuan (Tabel 3).

Tabel 1. Kriteria inklusi dan eksklusi pencarian literatur berdasarkan PICOS framework

\begin{tabular}{lll}
\hline Kriteria & Inklusi & Eksklusi \\
\hline $\begin{array}{l}\text { Population/Problem } \\
\text { Intervention }\end{array}$ & $\begin{array}{l}\text { Gangguan/penyakit hati } \\
\text { Tanaman obat }\end{array}$ & $\begin{array}{l}\text { Selain gangguan/penyakit hati } \\
\text { Tanaman obat yang sudah distandarisasi (kunyit, } \\
\text { temulawak, meniran dan paliasa) }\end{array}$ \\
$\begin{array}{l}\text { Comparators } \\
\text { Outcomes }\end{array}$ & - & - \\
Study design & Efek hepatoprotektif & Tanaman obat yang menimbulkan efek hepatotoksik \\
Tahun Publikasi & 2015-2020 & Artikel review dieksklusi \\
Bahasa & Inggris, Indonesia & Sebelum 2015 dan sesudah 2020 \\
\end{tabular}

Tabel 2. Hasil pencarian literatur

\begin{tabular}{|c|c|c|c|}
\hline No & $\begin{array}{c}\text { Peneliti/ } \\
\text { Tahun }\end{array}$ & Judul Penelitian & Uji Statistik \\
\hline 1. & $\begin{array}{l}\text { Tazkia RR et al, } \\
2019 .{ }^{8}\end{array}$ & $\begin{array}{l}\text { Efek ekstrak air daun sirsak (Annona } \\
\text { muricata) terhadap kadar SOD dan MDA } \\
\text { hepar tikus Wistar induksi diet tinggi lemak } \\
\text { dan tinggi fruktosa }\end{array}$ & $\begin{array}{l}\text { Uji Kruskal Wallis: } \mathrm{p}<0,05 \\
\text { Uji Mann-Whitney: } \mathrm{p}<0,05\end{array}$ \\
\hline 2. & $\begin{array}{l}\text { Nuari DA et al, } \\
2018 .^{9}\end{array}$ & $\begin{array}{l}\text { Aktivitas hepatoprotektor ekstrak etanol } \\
\text { rebung bambu kuning (Bambusa vulgaris } \\
\text { Schard) pada tikus putih jantan galur Wistar }\end{array}$ & $\begin{array}{l}\text { Kadar SGPT dan bilirubin: } p<0,05 \\
\text { Indeks organ hati: } p>0,05\end{array}$ \\
\hline 3. & $\begin{array}{l}\text { Kumala N et al, } \\
\text { 2016. }\end{array}$ & $\begin{array}{l}\text { Potensi ekstrak daun kelor (Moringa } \\
\text { Oleifera) sebagai hepatoprotektor pada tikus } \\
\text { putih (Rattus Novergicus) yang diinduksi } \\
\text { parasetamol dosis toksis }\end{array}$ & $\begin{array}{l}\text { Paired Samples T-Test: SGOT dan } \\
\text { SGPT (KP1 dan KP } 2 \text { p }>0,05 \text {, } \\
\text { sedangkan KP3 } \mathrm{p}<0,05) \text {. MDA } \\
(\mathrm{KP} 1, \mathrm{KP} 2 \text { dan KP3 }<<0,05)\end{array}$ \\
\hline 4. & $\begin{array}{l}\text { Oktavia S et al, } \\
2017 .^{11}\end{array}$ & $\begin{array}{l}\text { Uji aktivitas hepatoprotektor ekstrak daun } \\
\text { sirih hijau (Piper betle Linn.) terhadap } \\
\text { kerusakan hati yang diinduksi parasetamol }\end{array}$ & Uji ANOVA dua arah: $\mathrm{p}<0,05$ \\
\hline 5. & $\begin{array}{l}\text { Sadiyah H et al, } \\
\text { 2019.12 }\end{array}$ & $\begin{array}{l}\text { Potensi ekstrak buah libo (Ficus variegate, } \\
\text { Blume) sebagai hepatoprotektor pada tikus } \\
\text { (Rattus novergicus) }\end{array}$ & Uji ANOVA satu arah: $\mathrm{p}<0,05$ \\
\hline 6. & $\begin{array}{l}\text { Novianto A, } \\
\text { Hartono, 2016. }{ }^{13}\end{array}$ & $\begin{array}{l}\text { Uji aktivitas hepatoprotektor fraksi etil asetat } \\
\text { kenikir (Cosmos caudatus) terhadap tikus } \\
\text { yang diinduksi paracetamol }\end{array}$ & Uji ANOVA satu arah: $p<0,05$ \\
\hline 7. & $\begin{array}{l}\text { Hayong N et al, } \\
2019 . .^{14}\end{array}$ & $\begin{array}{l}\text { Efek ekstrak etanol daun mimba (Azadi- } \\
\text { rachta indica) terhadap kadar serum } \\
\text { glutamat piruvate transminase (SGPT) dan } \\
\text { gambaran histopatologi hepar pada mencit } \\
\text { (Mus musculus) model hepatotoksik }\end{array}$ & $\begin{array}{l}\text { Uji ANOVA satu arah dan uji } \\
\text { Duncan. } \\
\text { Nilai signifikansi analisis lanjutan } \\
\text { uji Duncan untuk KP1 dan KP2 } \\
\text { p }>0,05 \text {, sedangkan KP3 p }<0,05\end{array}$ \\
\hline 8. & Sediarso, $2018 .^{15}$ & $\begin{array}{l}\text { Ekstrak biji petai (Parkia Spesiosa Hassk) } \\
\text { sebagai hepatoprotektor berdasarkan kadar } \\
\text { SGPT, SGOT dan histologi hati tikus putih } \\
\text { jantan yang diinduksi } \mathrm{CCl}_{4}\end{array}$ & $\begin{array}{l}\text { Uji ANOVA satu arah: } \mathrm{p}<0,05 \\
\text { Uji Tukey HSD: } \mathrm{p}<0,05\end{array}$ \\
\hline 9. & $\begin{array}{l}\text { Afdin RR, } \\
\text { Quzwain F, } \\
2018 .{ }^{16}\end{array}$ & $\begin{array}{l}\text { Efek hepatoprotektor ekstrak jintan hitam } \\
\text { (Nigella sativa) terhadap kerusakan hepar } \\
\text { tikus putih (Rattus norvegicus) jantan galur } \\
\text { Sparague Dawley yang diinduksi etanol }\end{array}$ & $\begin{array}{l}\text { Uji Kruskal Wallis: }=0,001 . \\
\text { Uji Mann-Whitne: (KP \& KN } \\
\text { p=0,014), (KP \& KP1, KP \& KP2, } \\
\text { KP \& KP3 p=0,003), (KN \& KP1, } \\
\text { KN \& KP2, KN \& KP3 p=0,317), }\end{array}$ \\
\hline
\end{tabular}


(KP1 \& KP2, KP1 \& KP3, KP2 \&

$\mathrm{KP} 3 \mathrm{p}=1)$

10. Harianto et al, Uji efektivitas sifat hepatoprotektor

ANOVA: $\mathrm{p}<0,05$ 2019. ${ }^{17}$ ekstrak bawang lanang pada tikus Wistar jantan yang diinduksi parasetamol

Tabel 3. Populasi penelitian dan perlakuan terhadap hewan coba

\begin{tabular}{|c|c|c|c|c|}
\hline No & $\begin{array}{c}\text { Peneliti/ } \\
\text { Tahun }\end{array}$ & $\begin{array}{c}\text { Tanaman } \\
\text { Obat }\end{array}$ & $\begin{array}{c}\text { Populasi } \\
\text { Penelitian }\end{array}$ & Kelompok Perlakuan \\
\hline 1. & $\begin{array}{l}\text { Tazkia RR et } \\
\text { al, 2019. }{ }^{8}\end{array}$ & $\begin{array}{l}\text { Daun sirsak } \\
\text { (Annona } \\
\text { muricata) }\end{array}$ & $\begin{array}{l}\text { Tikus Wistar } \\
\text { jantan, bobot } \\
\text { badan 150-200 } \\
\text { gram, umur } \\
\text { sekitar } 8-10 \\
\text { minggu }\end{array}$ & $\begin{array}{l}\text { Total hewan coba } 25 \text { ekor tikus dibagi dalam } 5 \\
\text { kelompok perlakuan yaitu : } \\
\text { 1. Kontrol negatif }(\mathrm{KN})=\text { diet normal + air } \\
\text { 2. Kontrol positif }(\mathrm{KP})=\text { diet tinggi lemak dan } \\
\text { tinggi fruktosa (TLTF) + air } \\
\text { 3. Perlakuan } 1(\mathrm{KP} 1)=\text { diet TLTF + infusa } \\
\text { daun sirsak (IDS) } 100 \mathrm{mg} / \mathrm{kgBB} \\
\text { 4. Perlakuan } 2(\mathrm{KP} 2)=\text { diet TLTF + IDS } 200 \\
\text { mg/kgBB } \\
\text { 5. Perlakuan } 3(\mathrm{KP} 3) \text { diet TLTF + IDS } 400 \\
\text { mg/kgBB. } \\
\text { Perlakuan terhadap hewan coba dilaksanakan } \\
\text { selama } 70 \text { hari }\end{array}$ \\
\hline 2. & $\begin{array}{l}\text { Nuari DA et al, } \\
\text { 2018. }{ }^{9}\end{array}$ & $\begin{array}{l}\text { Rebung } \\
\text { bambu kuning } \\
\text { (Bambusa } \\
\text { vulgaris } \\
\text { Schard) }\end{array}$ & $\begin{array}{l}\text { Tikus putih } \\
\text { jantan galur } \\
\text { Wistar, } \\
\text { dengan } \\
\text { bobot badan } \\
200-300 \\
\text { gram }\end{array}$ & 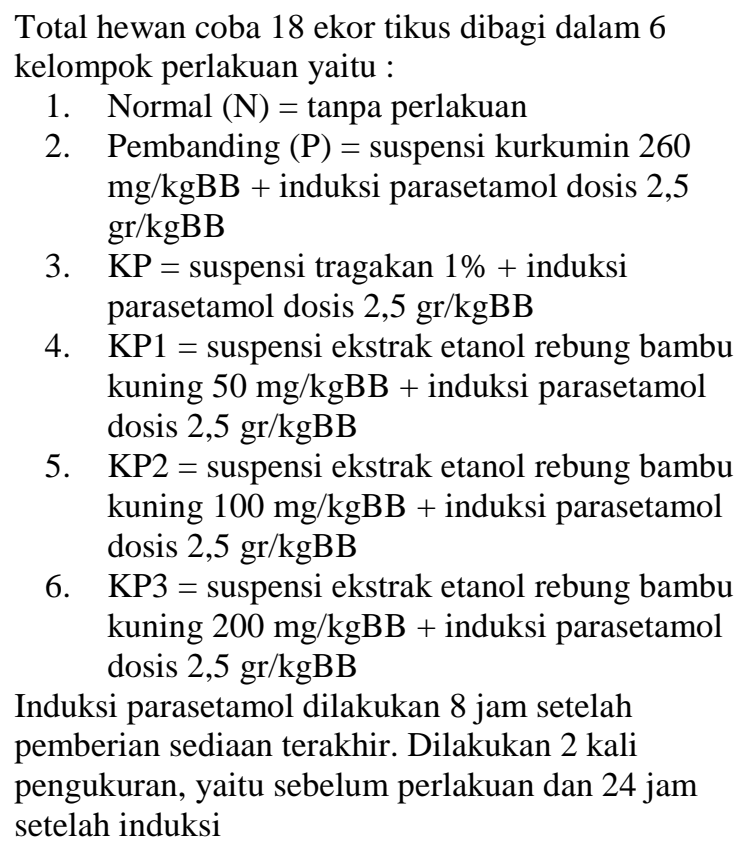 \\
\hline 3. & $\begin{array}{l}\text { Kumala N et } \\
\text { al, 2016. }{ }^{10}\end{array}$ & $\begin{array}{l}\text { Daun kelor } \\
\text { (Moringa } \\
\text { Oleifera) }\end{array}$ & $\begin{array}{l}\text { Tikus putih } \\
\text { galur } \\
\text { Wistar, } \\
\text { dengan } \\
\text { bobot badan } \\
200-300 \\
\text { gram }\end{array}$ & $\begin{array}{l}\text { Total hewan coba } 25 \text { ekor tikus dibagi dalam } 5 \\
\text { kelompok perlakuan yaitu : } \\
\text { 1. } \mathrm{KP}=\text { diberi pakan biasa }+ \text { aquadest selama } \\
14 \text { hari } \\
\text { 2. } \mathrm{KN}=\text { aquadest selama } 10 \text { hari }+ \text { parasetamol } \\
2 \mathrm{gr} / 200 \mathrm{grBB} \text { tikus pada hari ke } 7 \\
\text { 3. } \mathrm{KP} 1=\text { ekstrak etanol daun kelor } 250 \\
\mathrm{mg} / 200 \mathrm{grBB} \text { selama } 14 \text { hari }+ \text { parasetamol } 2 \\
\mathrm{gr} / 200 \mathrm{grBB} \text { pada hari ke } 7 \\
\text { 4. } \mathrm{KP} 2=\text { ekstrak etanol daun kelor } 500 \\
\mathrm{mg} / 200 \mathrm{grBB} \text { selama } 14 \text { hari }+ \text { parasetamol } 2 \\
\mathrm{gr} / 200 \mathrm{grBB} \text { pada hari ke } 7 \\
\text { KP3 = ekstrak etanol daun kelor } 1000 \\
\mathrm{mg} / 200 \mathrm{grBB} \text { selama } 14 \text { hari }+ \text { parasetamol } 2 \\
\mathrm{gr} / 200 \mathrm{grBB} \text { pada hari ketujuh }\end{array}$ \\
\hline 4. & Oktavia $\mathrm{S}$ et al, & Daun sirih & Mencit & Total hewan coba 45 ekor tikus dibagi dalam 5 \\
\hline
\end{tabular}




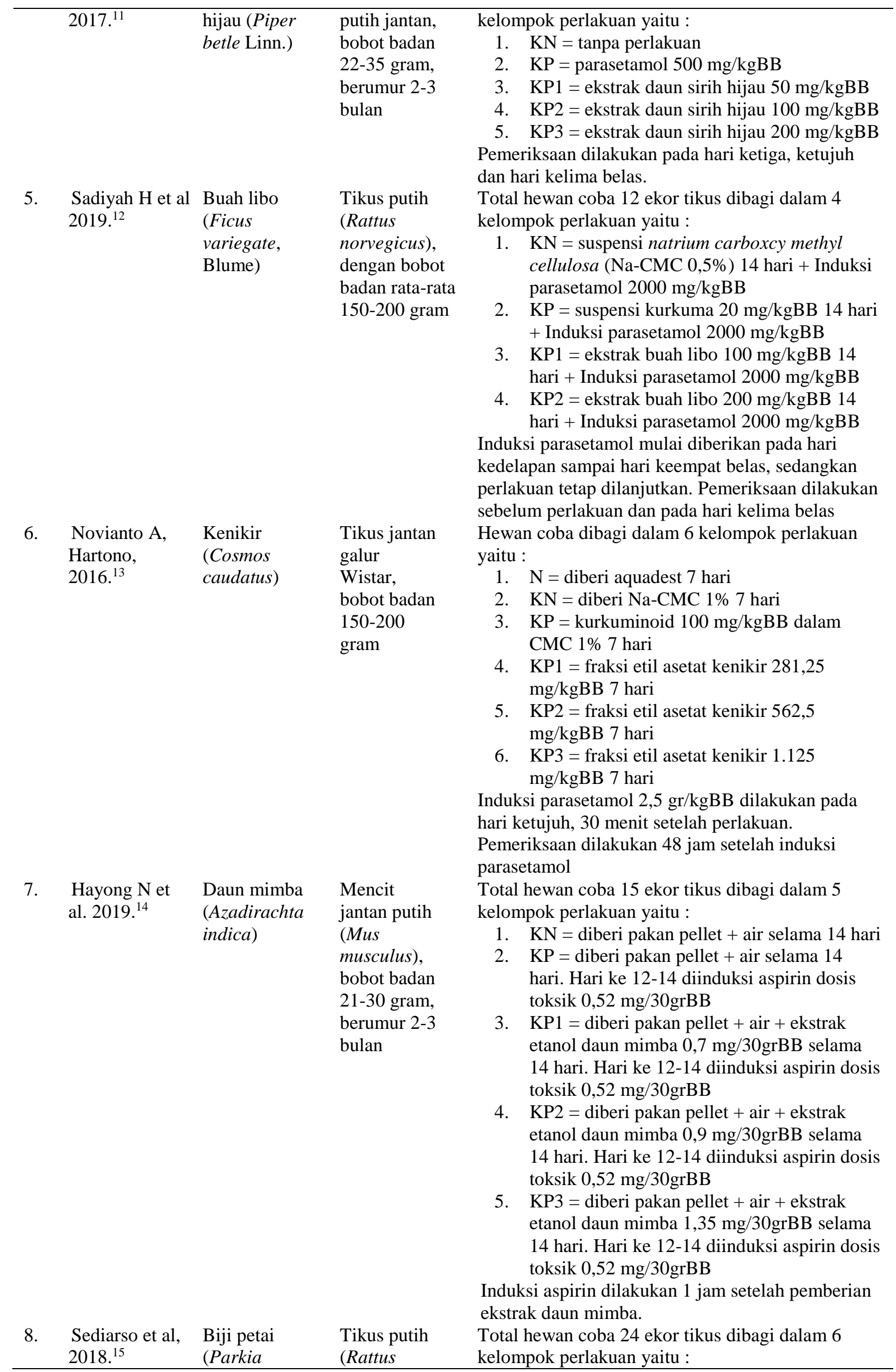




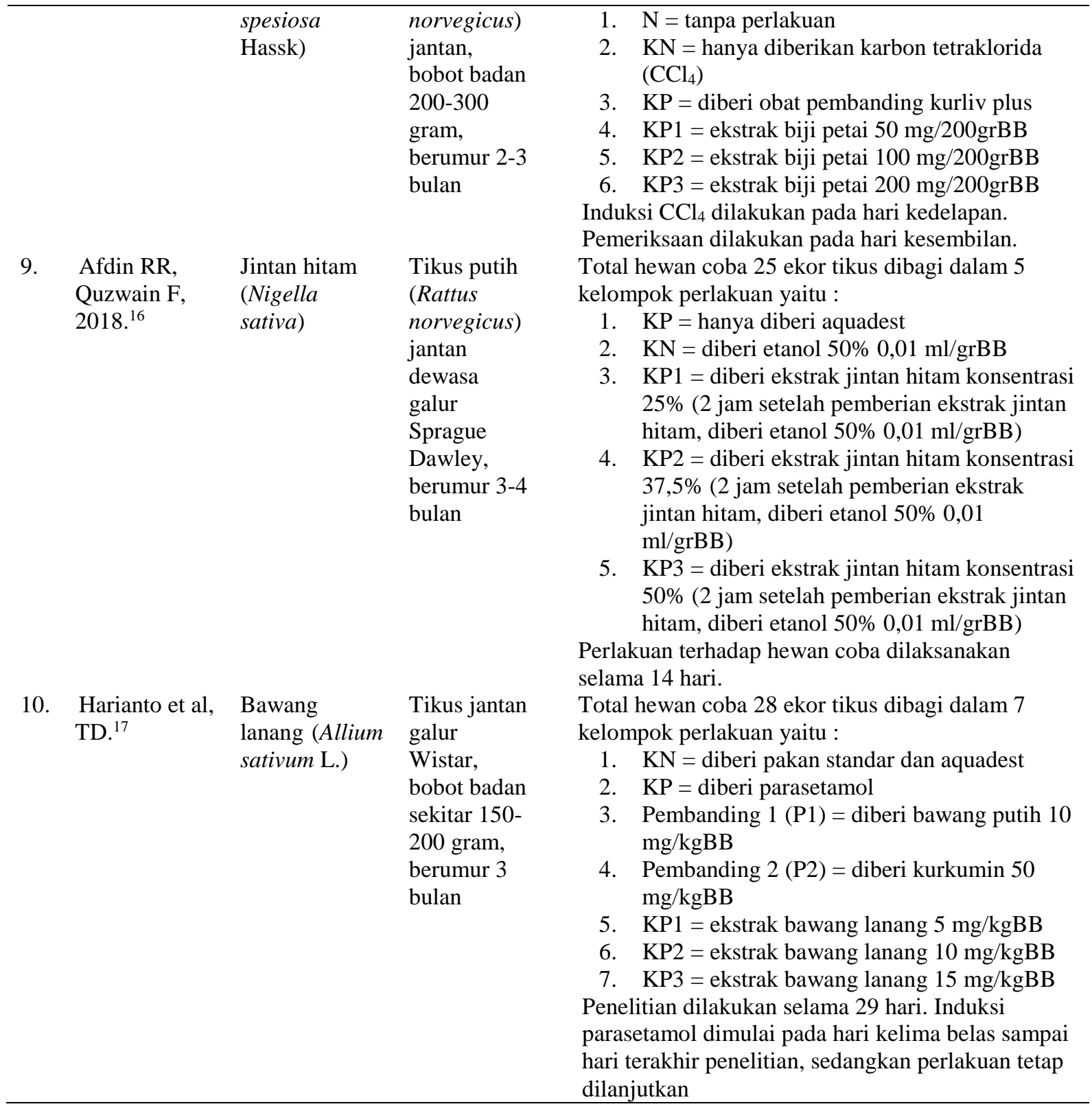

Literatur pertama yakni penelitian oleh Tazkia et $\mathrm{al}^{8}$ yang melaporkan bahwa berdasarkan hasil analisis uji Kruskall Wallis didapatkan perbedaan bermakna pada kadar SOD. Uji Mann-Whitney menunjukkan adanya perbedaaan bermakna $(\mathrm{p}<0,05) \mathrm{KP}$ terhadap KN, KP1, KP2 dan $\mathrm{KP}$, sedangkan KN tidak berbeda bermakna $(p>0,05)$ terhadap KP3. Dari hasil analisis diketahui bahwa semakin tinggi dosis, semakin tinggi juga kadar SOD. Berdasarkan uji Kruskall Wallis didapatkan perbedaan bermakna pada kadar MDA. Kontrol positif berbeda bermakna $(\mathrm{p}<0,05)$ terhadap KN, KP1, KP2 dan KP3, sedang- kan pada $\mathrm{KN}$ tidak berbeda bermakna (p>0,05) terhadap KP2 dan KP3. Kadar MDA menurun dengan pemberian IDS, semakin tinggi dosis semakin rendah kadar MDA. Hasil analisis data menunjukkan bahwa ekstrak air daun sirsak mempunyai efek sebagai hepatoprotektor karena dapat menurunkan kadar SOD dan meningkatkan kadar MDA hati. ${ }^{8}$

Literatur kedua yakni penelitian oleh Nuarie et $\mathrm{al}^{9}$ untuk mengetahui aktivitas hepatoprotektor dari ekstrak etanol rebung bambu kuning. Hasil penelitian mendapatkan bahwa ekstrak etanol rebung bambu kuning dosis 50, 100 dan $200 \mathrm{mg} / \mathrm{kgBB}$ 
dapat mempertahankan aktivitas SGPT dan kadar bilirubin pada hewan coba dan berbeda bermakna terhadap kontrol positif $(\mathrm{p}<0,05)$, namun aktivitasnya masih kecil jika dibandingkan dengan kurkumin. Perubahan kadar SGPT dan bilirubin hewan coba yang diberi kurkumin lebih kecil dibandingkan ketiga kelompok uji. Kadar SGPT hewan coba yang diberi ekstrak etanol rebung bambu kuning dosis 100 dan $200 \mathrm{mg} / \mathrm{kgBB}$ tidak berbeda bermakna terhadap kelompok yang diberi kurkumin sebagai pembanding $(\mathrm{p}>0,05)$. Namun untuk bilirubin, hanya dosis $200 \mathrm{mg} / \mathrm{kgBB}$ saja yang tidak berbeda bermakna terhadap kelompok pembanding ( $p>0,05)$. Dari hasil tersebut, dapat disimpulkan bahwa ekstrak etanol rebung bambu kuning dosis 200 $\mathrm{mg} / \mathrm{kgBB}$ lebih efektif dibandingkan dosis lain dalam mempertahankan fungsi hati mendekati kurkumin. Berdasarkan indeks organ hati tikus, semua kelompok dibandingkan terhadap kelompok normal dan secara statistik tidak menunjukkan perbedaan bermakna ( $p>0,05)$. Hal ini menunjukkan bahwa induktor hepatotoksik parasetamol $2,5 \mathrm{~g} / \mathrm{kgBB}$ tidak menyebabkan atrofi maupun hipertrofi pada hati tikus. ${ }^{9}$

Literatur ketiga yakni penelitian oleh Kumala et $\mathrm{al}^{10}$ yang menggunakan uji Paired Samples T-Test untuk membandingkan pengaruh tiga dosis ekstrak daun kelor terhadap kelompok kontrol positif maupun kelompok kontrol negatif terhadap kadar SGOT dan SGPT. Hasil menunjukkan bahwa dosis $1000 \mathrm{mg} / 200 \mathrm{grBB}$ dapat menurunkan kadar SGOT dan SGPT KP3 secara bermakna jika dibandingkan dengan kelompok kontrol negatif karena nilai $\mathrm{p}<\alpha(0,05)$. Dosis $250 \mathrm{mg} / 200 \mathrm{grBB}$ pada KP1 dan dosis $500 \mathrm{mg} / \mathrm{kgBB}$ pada KP2 tidak memberikan pengaruh bermakna dibandingkan dengan kelompok kontrol. Dengan uji yang sama untuk pengaruh dosis parasetamol dosis toksik juga memberikan pengaruh adanya kenaikan kadar SGOT dan SGPT pada kelompok kontrol negatif jika dibandingkan kelompok kontrol positif karena nilai $\mathrm{p}<\alpha$ $(0,05)$. Hal ini menunjukkan bahwa dosis toksik parasetamol dapat meningkatkan kadar SGOT maupun SGPT pada kelompok kontrol negatif dan pemberian ekstrak daun kelor $1000 \mathrm{mg} / 200 \mathrm{grBB}$ efektif menurunkan kadar SGOT dan SGPT pada hewan coba. Untuk kadar MDA, hasil penelitian menunjukkan bahwa dosis $250 \mathrm{mg} /$ $200 \mathrm{grBB}, 500 \mathrm{mg} / 200 \mathrm{grBB}$ dan 1000 mg/200grBB dapat menurunkan kadar MDA secara bermakna dibandingkan kelompok kontrol negatif karena nilai $\mathrm{p}<\alpha$ $(0,05)$. Hal ini menunjukkan adanya penurunan kadar MDA pada KP1, KP2 dan KP3 dibandingkan dengan kelompok kontrol negatif. Parasetamol dosis toksik juga memberikan pengaruh adanya kenaikan kadar MDA pada kelompok kontrol negatif jika dibandingkan dengan kelompok kontrol positif karena nilai $\mathrm{p}<\alpha(0,05)$, yang berarti bahwa dengan dosis toksik parasetamol dapat meningkatkan kadar MDA pada kelompok kontrol negatif dan pemberian ekstrak daun kelor $1000 \mathrm{mg} / 200 \mathrm{grBB}$ efektif menurunkan kadar MDA pada hewan coba. ${ }^{10}$

Literatur keempat yakni penelitian oleh Oktavia et al $^{11}$ untuk mengetahui aktivitas hepatoprotektor dari ekstrak daun sirih hijau pada mencit yang diinduksi parasetamol 500 $\mathrm{mg} / \mathrm{kgBB}$. Hasil penelitian menunjukkan bahwa induksi parasetamol pada hewan coba dapat menimbulkan kerusakan hati dimana terlihat tingginya kadar SGOT dan SGPT pada kelompok kontrol positif yang diberikan parasetamol dibandingkan dengan kadar SGOT dan SGPT pada kelompok kontrol negatif yang merupakan kelompok normal. Terdapat penurunan kadar SGOT dan SGPT seiring dengan peningkatan dosis ekstrak daun sirih hijau. Data penelitian dianalisis dengan menggunakan uji Anova dua arah dan hasil penelitian menunjukkan bahwa variasi dosis ekstrak daun sirih hijau menurunkan kadar SGOT dan SGPT dengan nilai signifikansi $(p>0,05)$ pada mencit yang sudah dirusak hatinya dengan parasetamol sedangkan lama pemberian ekstrak tidak memengaruhi kadar SGOT dan SGPT (nilai signifikansi $\mathrm{p}<0,05)$. Penelitian dilanjutkan dengan uji Duncan dan didapatkan bahwa ketiga dosis ekstrak etanol daun sirih hijau memberi efek yang berbeda terhadap aktivitas SGOT dan SGPT. Aktivitas penurunan 
SGOT dan SGPT paling tinggi ditunjukkan pada dosis $200 \mathrm{mg} / \mathrm{kgBB}$. Selain pemeriksaan kadar SGOT dan SGPT, dilakukan juga pemeriksaan histopatologik untuk melihat aktivitas hepatoprotektor daun sirih hijau. Pada kelompok kontrol negatif pemeriksaan histopatologik hari ketiga, hari ketujuh dan hari kelima belas menunjukkan tidak ada nekrosis sentrolobular. Pada kelompok kontrol positif pemeriksaan histopatologik hari ketiga menunjukkan adanya nekrosis sentrolobular ringan, hari ketujuh menunjukkan nekrosis sentrolobular ringan serta adanya sel limfosit, dan hari ke-15 menunjukkan adanya nekrosis sentrolobular. Hal ini membuktikan bahwa pemberian parasetamol dosis $500 \mathrm{mg} / \mathrm{kgBB}$ selama 15 hari pada mencit dapat menyebabkan nekrosis hati sentrolobular. Pemeriksaan histopatologik hati pada KP1, KP2 dan KP3 menunjukkan gambaran mikroskopik hati mencit yang mengalami perbaikan nekrosis sentrolobular. Hal ini membuktikan bahwa ekstrak daun sirih hijau dapat memperbaiki hepatosit berdasarkan gambaran histopatologik hati. ${ }^{11}$

Literatur kelima yakni penelitian oleh Sadiyah et al $^{12}$ untuk mengetahui potensi ekstrak buah libo sebagai hepatoprotektor. Berdasarkan hasil pengukuran sebelum perlakuan pada semua kelompok didapatkan kadar SGOT masih rendah, kemudian mengalami peningkatan setelah perlakuan. Sebelum perlakuan, semua kelompok memiliki kadar SGPT yang rendah, namun setelah perlakuan didapatkan bahwa kelompok kontrol negatif mengalami kenaikan kadar SGPT. Pada kontrol negatif hanya diberikan suspensi Na-CMC $0,5 \%$ dan kemudian diinduksi dengan parasetamol dosis $2000 \mathrm{mg} / \mathrm{kgBB}$, sehingga disimpulkan bahwa pemberian parasetamol dapat menimbulkan kerusakan hati yang ditandai dengan peningkatan kadar SGOT dan SGPT. Pada kelompok kontrol positif kadar SGPT mengalami penurunan; hal ini disebabkan karena pada kontrol positif diberikan Curcuma ${ }^{\circledR}$ dengan dosis $20 \mathrm{mg}$ yang memiliki aktivitas hepatoprotektor. Pada KP1 yang diberikan ekstrak buah libo $100 \mathrm{mg} / \mathrm{kgBB}$ terjadi peningkatan kadar
SGPT, yang berarti pada dosis tersebut tidak memiliki potensi sebagai hepatoprotektor. Pada KP2 dengan dosis $200 \mathrm{mg} / \mathrm{kgBB}$ terjadi penurunan nilai SGPT atau nilai SGPT tetap dalam keadaan normal, yang berarti pada dosis tersebut memiliki potensi sebagai hepatoprotektor tetapi efeknya lebih kecil dibandingkan curcuma®. Berdasarkan uji statistik One Way ANOVA didapatkan perbedaan bermakna dari kadar SGOT dan SGPT. ${ }^{12}$

Literatur keenam yakni penelitian oleh Novianto dan Hartono ${ }^{13}$ untuk mengetahui aktivitas hepatoprotektor fraksi etil asetat kenikir pada tikus yang diinduksi parasetamol. Berdasarkan uji statistik menggunakan metode one way Anova, didapatkan efek induksi parasetamol dosis toksik 2,5 gr/kgBB mampu memberikan kenaikan parameter biokimia darah (SGOT dan SGPT) secara bermakna $(p<0,05)$ pada kelompok kontrol negatif dibandingkan kelompok normal dan kelompok pembanding yang diberi kurkuminoid. Dilihat dari parameter biokimia darah SGPT, fraksi etil asetat kenikir memiliki aktivitas hepatoprotektor karena mampu menekan kenaikan SGPT. Semakin tinggi dosis yang diberikan maka efek hepatoprotektor semakin meningkat. Dosis tertinggi yaitu $1125 \mathrm{mg} / \mathrm{kg}$ BB yang diberikan pada KP3 menunjukkan efek hepatoprotektor secara bermakna $(\mathrm{p}<0,05)$. Hal ini juga didukung dengan parameter biokimia SGOT dimana fraksi etil asetat kenikir dosis $1125 \mathrm{mg} / \mathrm{kg}$ BB pada KP3 memberikan respon nilai SGOT terendah dibandingkan dengan dua fraksi etil asetat kenikir yang diberikan pada KP1 dan KP2. ${ }^{13}$

Literatur ketujuh yakni penelitian oleh Hayong et $\mathrm{al}^{14}$ mengenai efek hepatoprotektor ekstrak etanol daun mimba. Uji one way Anova menunjukkan bahwa pada KP1 dan KP2 terdapat pengaruh nyata pemberian ekstrak etanol daun mimba terhadap gambaran kerusakan sel hati yang diinduksi aspirin. Hasil analisis dilanjutkan dengan uji Duncan dan diperoleh nilai signifikansi $(>0,05)$. Meskipun pada penilaian kadar SGPT KP1 mengalami peningkatan dan mengalami penurunan pada KP2, 
hal ini tidak memiliki korelasi positif dengan gambaran kerusakan hepar yang terjadi. Kelompok perlakuan 3 yang diberikan ekstrak etanol 1,35 mg/30grBB memiliki gambaran kerusakan hati yang lebih parah dari KP1 dan KP2 yang diberi ekstrak etanol daun mimba sebanyak 0,7 $\mathrm{mg} / 30 \mathrm{grBB}$ dan $0,9 \mathrm{mg} / 30 \mathrm{grBB}$ (nilai signifikansi $<0,05)$. Diduga dosis pemberian yang berlebihan dari ekstrak etanol daun mimba dapat menimbulkan kerusakan sel hati. Oleh karena itu, dosis ekstrak etanol daun mimba yang efektif untuk melindungi hati dari kerusakan yang diinduksi aspirin yaitu $0,7 \mathrm{mg} / 30 \mathrm{grBB}$ dan $0,9 \mathrm{mg} / 30 \mathrm{grBB}$. Pemberian dosis $1,35 \mathrm{mg} / 30 \mathrm{grBB}$ sudah menunjukkan kerusakan hepar yang lebih parah dibandingkan dengan KP1 dan KP2. ${ }^{14}$

Literatur kedelapan yakni penelitian oleh Sediarso dan Saputra ${ }^{15}$ mengenai efek hepatoprotektor ekstrak biji petai. Berdasarkan uji Anova satu arah didapatkan $\mathrm{p}<0,05$ yang menunjukkan adanya efektivitas biji petai sebagai hepatoprotektor. Analisis data dilanjutkan dengan uji Tukey HSD untuk mengetahui perbedaan yang ada dan hasil uji statistik menunjukkan adanya perbedaan bermakna dari kadar SGOT dan SGPT kontrol negatif dengan semua kelompok perlakuan. Hal ini terjadi karena kontrol negatif hanya diinduksi dengan $\mathrm{CCL}_{4}$ dan tidak diberikan obat pembanding atau ekstrak biji petai. Dari hasil data statistik rerata kadar SGPT dan SGOT menunjukan tidak adanya perbedaan antara KP3 dengan kontrol normal dan kontrol positif. Uji statistik rerata diameter vena sentralis menunjukan bahwa terdapat perbedaan bermakna antara kontrol negatif, KP1, dan KP2 dengan kontrol normal, kontrol positif, dan KP3. Hal ini menyatakan bahwa ekstrak biji petai dosis $200 \mathrm{mg} / 200 \mathrm{grBB}$ yang diberikan pada KP3 memiliki efektivitas yang sama dengan kontrol normal dan kontrol positif. Berdasarkan semua data yang ada, dapat disimpulkan bahwa ekstrak biji petai memiliki efektivitas sebagai hepatoprotektor dengan dosis efektif 200 $\mathrm{mg} / 200 \mathrm{grBB} .^{15}$

Literatur kesembilan yakni penelitian oleh Afdin dan Quzwain ${ }^{16}$ mengenai efek hepatoprotektor ekstrak jintan hitam. Berdasarkan hasil penelitian, gambaran degenerasi lemak yang terjadi pada kelompok kontrol negatif terlihat cukup banyak daripada empat kelompok lainnya. Hal ini terjadi karena kontrol negatif hanya diberi etanol yang dapat merusak hati, sedangkan kontrol normal hanya diberi akuades, serta KP1, KP2 dan KP3 diberikan ekstrak jintan hitam sebagai hepatoprotektor. Kelompok perlakuan 1 dengan konsentrasi dosis ekstrak jintan hitam $25 \%$ sudah mulai menunjukkan perbaikan gambaran histopatologik hati dibandingkan dengan kontrol negatif berdasarkan gambaran degenerasi lemak. Kelompok perlakuan 2 yang diberikan ekstrak jintan hitam dengan konsentrasi dosis $37,5 \%$ juga memperlihatkan perbaikan dibandingkan KP1, sedangkan pada KP3 dengan konsentrasi dosis 50\% memperlihatkan perbaikan dengan gambaran degenerasi lemak yang paling sedikit dijumpai dibandingkan kelompok kontrol negatif, KP1 dan KP2. Dari hasil penelitian dapat disimpulkan bahwa ekstrak jintan hitam memiliki efek hepatoprotektor terhadap kerusakan hati tikus putih (Rattus norvegicus) jantan galur Sparague Dawley yang diinduksi etanol. ${ }^{16}$

Literatur kesepuluh yakni penelitian oleh Harianto et al $^{17}$ untuk mengetahui efek hepatoprotektor dari ekstrak bawang lanang. Hasil pengukuran kadar SGPT menunjukkan bahwa ekstra bawang lanang dengan tiga dosis berbeda memiliki kemampuan dalam menurunkan kadar SGPT disbandingkan dengan perlakuan lainnya. Hasil pengukuran kadar SGOT menunjukkan bahwa ekstrak bawang lanang memberikan efek proteksi lebih tinggi dibandingkan kurkumin dan ekstrak bawang putih yang merupakan pembanding. Berdasarkan hasil pengukuran kadar MDA serum diketahui bahwa ekstrak bawang lanang dosis 5 $\mathrm{mg} / \mathrm{kgBB}, 10 \mathrm{mg} / \mathrm{kgBB}$, dan $15 \mathrm{mg} / \mathrm{kgBB}$ memiliki persentase kenaikan yang cenderung lebih rendah dibandingkan dengan kelompok kontrol positif, kelompok perlakuan kurkumin, serta kelompok perlakuan bawang putih. Seiring dengan meningkatnya dosis ekstrak bawang lanang, 
persentase peningkatan kadar MDA juga semakin kecil. Hal ini menyatakan bahwa semakin tinggi dosis ekstrak bawang lanang yang diberikan maka peningkatan kadar MDA yang terjadi setelah diinduksi parasetamol dosis toksik juga semakin kecil. Dari hasil pengukuran kadar SOD serum pada hewan coba, diketahui bahwa pemberian ekstrak bawang lanang dengan tiga dosis yang berbeda memiliki persentase penurunan kadar SOD akibat induksi parasetamol dosis toksik yang lebih kecil dibandingkan kelompok perlakuan lainnya. Pada hati tikus yang diberikan ekstrak bawang lanang dosis $15 \mathrm{mg} / \mathrm{kgBB}$ menunjukan gambaran sel hati yang hampir sama dengan sel hati normal. Hal ini menunjukkan bahwa bawang lanang memiliki kemampuan yang lebih baik dalam menekan jumlah sel yang mengalami nekrosis dibandingkan dengan kelompok yang diberi kurkumin dan bawang putih. ${ }^{17}$

\section{BAHASAN}

Berdasarkan telaah pustaka yang dilakukan ini, diketahui bahwa kesepuluh tanaman obat hepatoprotektor yang diteliti mengandung senyawa flavonoid yang berperan sebagai antioksidan. Antioksidan secara langsung melindungi sel hati dari radikal bebas melalui penhambatan oksidasi radikal bebas, sedangkan secara tidak langsung dapat memelihara fungsi hati dengan menetralisir radikal bebas yang dapat menganggangu atau menghambat laju asupan nutrisi dan mineral yang dibutuhkan organ hati dalam menjalankan fungsinya. ${ }^{18}$ Mekanisme antioksidan senyawa flavonoid yaitu menangkap ROS secara langsung, mencegah terjadinya regenerasi ROS, dan secara tidak langsung dapat meningkatkan aktivitas enzim antioksidan seluler. Flavonoid merupakan senyawa polifenol yang paling efektif untuk meredam radikal bebas (free radical scavanger), misalnya super dioksida, peroksinitrit, dan radikal peroksil dengan cara mentransfer atom $\mathrm{H}+$. Flavonoid mencegah terbentuknya ROS dengan beberapa cara, yaitu menghambat kerja enzim xantin oksidase dan nikotinamide adenine dinucleotide phosphate (NADPH) oksidase, serta mengkelat logam
$\left(\mathrm{Fe}^{2+}\right.$ dan $\left.\mathrm{Cu}^{2+}\right)$ sehingga dapat mencegah reaksi redoks yang dapat menghasilkan radikal bebas. Flavonoid merupakan antioksidan eksogen yang berfungsi melindungi antioksidan lipofilik sehingga dapat mengoptimalkan antioksidan seluler. ${ }^{19}$

Daun sirsak mengandung senyawa flavonoid, tanin, fitosterol, kalsium oksalat, dan alkaloid. Senyawa-senyawa tersebut, terutama flavonoid yang merupakan senyawa polifenol dapat mereduksi radikal bebas. Hasil penelitian menunjukkan bahwa semakin tinggi dosis ekstrak air daun sirsak semakin besar pula potensi antioksidannya, sehingga dosis $400 \mathrm{mg} / \mathrm{kgBB}$ efektif meningkatkan kadar SOD dan menurunkan kadar MDA hati. ${ }^{8}$ Kandungan flavonoid dan tanin dalam rebung bambu kuning menyatakan bahwa rebung bambu kuning berkhasiat sebagai hepatoprotektor, sehingga mampu mempertahankan aktivitas SGPT dan kadar bilirubin hewan coba. Pemberian ekstrak etanol rebung bambu kuning dosis 200 $\mathrm{mg} / \mathrm{kgBB}$ lebih efektif dibandingan dosis lain. ${ }^{9}$ Daun kelor mengandung vitamin $\mathrm{C}$, alkaloid, flavonoid, saponin, fitosterol, fenolik, dan tanin. Kandungan flavonoid pada ekstrak daun kelor memiliki potensi sebagai antioksidan sekaligus sebagai hepatoprotektor dengan dosis efektif $1 \mathrm{gr} /$ 200grBB, karena dapat menurunkan kadar SGOT, SGPT, dan MDA pada hewan coba. Aktivitas antioksidatif flavonoid pada daun kelor ini bersumber pada kemampuan mendonasikan atom hidrogen atau mengkelat logam. ${ }^{10}$

Senyawa alkaloid, flavonoid, steroid, dan terpenoid pada daun sirih hijau menyatakan adanya aktivitas antioksidan sehingga tanaman ini memiliki daya proteksi terhadap kerusakan hati. ${ }^{11}$ Dari penelitian diketahui bahwa variasi dosis ekstrak daun sirih hijau bersifat hepatoprotektor dengan memengaruhi penurunan SGOT dan SGPT, serta dapat memperbaiki nekrosis sentrolobuler hati mencit yang diinduksi parasetamol. ${ }^{11}$ Buah libo memiliki potensi sebagai hepatoprotektor karena adanya kandungan flavonoid yang menunjukkan aktivitas antioksidatif, dengan dosis efektif $200 \mathrm{mg} / \mathrm{kgBB}$ karena dapat menurunkan 
aktivitas SGPT pada hewan coba, tetapi efeknya lebih kecil dibandingkan dengan curcuma. ${ }^{12}$ Fraksi etil asetat kenikir dosis $1125 \mathrm{mg} / \mathrm{kgBB}$ menunjukkan efek hepatoprotektor dengan menurunkan parameter biokimia SGPT dan SGOT. Aktivitas hepatoprotektor kenikir dipicu oleh kandungan kuersetin yang merupakan metabolit sekunder flavonoid. ${ }^{13}$

Hasil penelitian membuktikan bahwa ekstrak etanol daun mimba dosis 0,7 $\mathrm{mg} / \mathrm{grBB}$ dan $0,9 \mathrm{mg} / \mathrm{grBB}$ efektif melindungi hati dari kerusakan yang diinduksi aspirin dosis toksik, sedangkan ekstrak etanol daun mimba dosis $1,35 \mathrm{mg} / \mathrm{grBB}$ sudah menunjukkan kerusakan hati. Daun mimba mengandung senyawa aktif kuersetin dan rutin yang dapat menghambat terjadinya proses oksidasi akibat radikal bebas. ${ }^{14}$ Penelitian menunjukkan bahwa dosis $200 \mathrm{mg} / 200 \mathrm{grBB}$ biji petai memiliki aktivitas hepatoprotektor berdasarkan hasil rerata kadar SGOT, SGPT, serta didukung dengan data statistik rerata diameter vena sentralis. ${ }^{15}$ Biji petai mengandung alkaloid, flavonoid, saponin, dan steroid yang memungkinkan adanya aktivitas antioksidan, sehingga biji petai bermanfaat sebagai hepatoprotektor. ${ }^{15}$

Ekstrak jintan hitam konsentrasi dosis $50 \%$ dapat bermanfaat sebagai hepatoprotektor pada hewan coba yang mengalami kerusakan hati akibat induksi etanol. Pemberian etanol pada hewan coba menyebabkan terbentuknya degenerasi lemak yang bermakna, namun ekstrak jintan hitam dengan konsentrasi dosis 50\% dapat mengurangi degenerasi lemak berdasarkan gambaran histopatologik. Kuersetin dan timokuinon yang terdapat dalam jintan hitam dapat mengurangi stres oksidatif dan meningkatkan pertahanan antioksidan tubuh. ${ }^{16}$ Bawang lanang mengandung senyawa fenol, flavonoid, dan organosulfur yang bermanfaat sebagai hepatoprotektor. Pemberian ekstrak bawang lanang dapat meningkatkan kadar SOD dan menurunkan kadar MDA serum darah, serta dapat menurunkan kadar SGOT dan SGPT pada hewan coba yang dipapar parasetamol dosis toksik. Aktivitas hepatoprotektor pada bawang lanang meningkat seiring dengan peningkatan dosis; oleh karena itu bawang lanang dengan dosis $15 \mathrm{mg} / \mathrm{kgBB}$ lebih efektif dari pada dosis lainnya. ${ }^{17}$

Dari 10 artikel yang ditelaah, parasetamol merupakan obat yang paling banyak digunakan untuk menginduksi kerusakan hati. Dalam keadaan overdosis parasetamol, mekanisme sulfat dan glukoronat konjugase menjadi jenuh sehingga tejadi peningkatan parasetamol yang dihidroksilasi oleh enzim sitokrom P-450 dan membentuk N-asetil-pbenzokuinon imin (NAPQI). Terjadinya peningkatan kecepatan dan jumlah pembentukan NAPQI melebihi persediaan dan regenerasi dari glutation (GSH) yang menyebabkan deplesi GSH seluler. Deplesi GSH menyebabkan NAPQI bebas berikatan secara kovalen dengan makromolekul sel hati sehingga lebih rentan terhadap stres oksidatif dan peroksidasi lipid yang akhirnya dapat menyebabkan nekrosis hati akut. Kerusakan pada sel hati menyebabkan peningkatan kadar enzim hati dalam darah karena keluarnya enzim hati intrasel dari sitosol dan organela menuju sinusoid. ${ }^{12}$

Berdasarkan telaah terhadap literatur yang diperoleh, parameter yang diperiksa dalam pengujian hepatoprotektor yaitu parameter biokimia dan histopatologik. Parameter biokimia meliputi pemeriksaan kadar SGOT, SGPT, SOD, MDA, dan bilirubin sedangkan pemeriksaan histopatologik untuk melihat adanya kerusakan pada sel hati.

Enzim SGPT merupakan indikator yang sensitif dalam mendeteksi adanya penyakit pada hati yang bersifat akut. Hal ini dimungkinkan oleh adanya pelepasan enzim SGPT ke aliran darah karena rusaknya hepatosit. Enzim SGPT merupakan enzim yang lebih spesifik dalam menentukan kerusakan sel hati dibandingkan SGOT dikarenakan SGPT ditemukan terutama di hati sedangkan SGOT dapat ditemukan pada bagian tubuh selain di hati, seperti di otot jantung, otot rangka, otak, ginjal, pankreas, sel darah merah, dan sel darah putih. Dengan demikian, jika hanya terjadi peningkatan enzim SGOT maka dapat saja yang mengalami kerusakan ialah sel-sel pada 
organ lainnya yang mengandung SGOT. ${ }^{12}$

Malondialdehid (MDA) merupakan senyawa yang menjadi penanda terjadinya stres oksidatif. Malondialdehid merupakan hasil oksidasi asam lemak tidak jenuh serta metabolit komponen sel yang dihasilkan oleh radikal bebas. Peningkatan kadar MDA menunjukkan proses oksidasi dalam membran sel dan apabila kapasitas antioksidan dalam jumlah yang cukup biasanya diikuti oleh penurunan kadar MDA. ${ }^{10}$ Peningkatan ROS yang tinggi dapat menyebabkan tubuh harus mengeluarkan antioksidan yang cukup banyak untuk menetralisir senyawa radikal tersebut. Superoksida dismutase merupakan antioksidan enzimatik yang memiliki peran penting dalam proses degradasi senyawa radikal bebas. Pada saat terjadi stres oksidatif, aktivitas SOD sangat meningkat untuk mengangkut oksigen dalam jumlah yang cukup tinggi yang dapat menyebabkan kadar SOD hati menurun, sedangkan kadar MDA mengalami peningkatan. ${ }^{8}$

Kandungan senyawa yang berkhasiat obat tidak sama pada setiap tanaman obat yang memiliki efek hepatoprotektif. Dengan demikian, kemampuan setiap tanaman obat untuk melindungi hepatosit dari kerusakan akan berbeda-beda, tergantung jenis dan jumlah senyawa aktif yang terkandung di dalamnya.

\section{SIMPULAN}

Terdapat 10 tanaman obat dengan efek hepatoprotektor, yaitu daun sirsak (Annona muricata), rebung bambu kuning (Bambusa vulgaris Schard), daun kelor (Moringa Oleifera), daun sirih hijau (Piper betle Linn.), buah libo (Ficus variegate, Blume), kenikir (Cosmos caudatus), daun mimba (Azadirachta indica), biji petai (Parkia spesiosa Hassk), jintan hitam (Nigella sativa), dan bawang lanang (Allium sativum L.). Kesepuluh tanaman obat tersebut mengandung antioksidan flavonoid dan memiliki kemampuan dalam meningkatkan kadar SOD; menurunkan kadar SGOT, SGPT dan MDA; mempertahankan kadar bilirubin; memperbaiki nekrosis sentrolobuler hati; dan mengurangi degenerasi lemak hati. Bawang lanang menunjukkan aktivitas hepatoprotektor terbesar, diikuti rebung bambu kuning, daun sirih hijau dan buah libo.

\section{Konflik Kepentingan}

Penulis menyatakan tidak terdapat konflik kepentingan dalam studi ini.

\section{DAFTAR PUSTAKA}

1. Guyton AC, Hall JE. Metabolism and temperature regulation. In: Widjajakusumah MD, editor. Guyton and Hall Textbook of Medical Physiology (12th ed). Saunders, an imprint of Elsevier Inc, 2011; p. 807-77.

2. Singh MP, Chourasia HR, Agarwal M, Malhotra A, Sharma M, Sharma D, et al. Honey as complementary medicine: - a review. Int J Pharma Bio Sci. 2012; 3(2):12-31.

3. Forbes SJ, Newsome PN. Liver regeneration mechanisms and models to clinical application. Nat Rev Gastroenterol Hepatol. 2016;13(8):473-85. Doi:10. 1038/nrgastro.2016.97

4. Ali M, Khan T, Fatima K, Ali QuA, Ovais M, Khalil AT, at al. Selected hepatoprotective herbal medicines: Evidence from ethnomedicinal applications, animal models, and possible mechanism of actions. Phyther Res. 2018;32(2):199215. Doi:10.1002/ptr.5957

5. World Health Organization (WHO). WHO Traditional Medicine Strategy 20142023. World Heal Organ. Published online 2013; p. 1-76. Available from: https://www.who.int/medicines/publica tions/traditional/trm_strategy14_23/en/

6. BPOM. Peraturan BPOM Nomor 32 Tahun 2019 Persyaratan Keamanan dan Mutu Obat Tradisional. Badan Pengawas Obat dan Makanan. Published online 2019:1-37. Doi:10.1017/CBO9781107 415324.004

7. Kementerian Kesehatan Republik Indonesia. Peraturan Menteri Kesehatan Republik Indonesia tentang Formularium Obat Herbal Asli Indonesia. Kemenkes RI. Published online 2016. Available from: http://hukor.kemkes.go.id/uploads/prod uk_hukum/PMK_No._6_ttg_Formulari um_Obat_Herbal_Asli_Indonesia_.pdf

8. Tazkia R, Amalia Y, Damayanti DS. The effects of soursop (Annona Muricata) leaves 
water extract in SOD and MDA hepar levels of Wistar rats induced high fat and high fructose diet. J Biokomplementer Med. 2019;6(3):1-8.

9. Nuari DA, Qowwiyah A, Eksyawati D. Aktivitas hepatoprotektor ekstrak etanol rebung bambu kuning (Bambusa vulgaris Schard) pada tikus putih jantan galur Wistar. J Ilm Farm Bahari. 2018; 9(2):16-22.

10. Kumala N, Masfufatun, Rianti EDD. Potensi ekstrak daun kelor (Moringa Oleifera) Sebagai hepatoprotektor pada tikus putih (Rattus Novergicus) yang diinduksi parasetamol dosis toksis. J Ilm Kedokt. 2016;5(1):58-66.

11. Oktavia S, Ifora, Suhatri, Susanti M. Uji aktivitas hepatoprotektor ekstrak daun sirih hijau (Piper Betle Linn.) terhadap kerusakan hati yang diinduksi parasetamol. Farm Higea. 2017;9(2):109-117.

12. Sadiyah H, Priastomo M, Rusli R. Potensi ekstrak buah libo (Ficus Variegate, Blume) sebagai hepatoprotektor pada tikus (Rattus Novergicus). Mulawarman Pharm Conf. Published online 2019:1-6.

13. Novianto A, Hartono. Uji aktivitas hepatoprotektor fraksi etil asetat kenikir (Cosmos Caudatus) terhadap tikus yang diinduksi parasemol. Indones J Med Sci. 2016;3(1):35-41.

14. Hayong N, Laut M, Pandarangga P. Efek ekstrak etanol daun mimba (Azadirachta indica) terhadap kadar serum glutamat piruvate transminase (SGPT) dan gambaran histopatologi hepar pada mencit
(Mus musculus) model hepatotoksik. Vet Nusant. 2019;2(2):72-84.

15. Sediarso, Saputra E, Efendi K. Ekstrak biji petai (Parkia Spesiosa Hassk) Sebagai hepatoprotektor berdasarkan kadar SGPT, SGOT dan histologi hati tikus putih jantan yang diinduksi CCL4. J Ilm Kesehat. 2018;10(September):181-9.

16. Afdin RR, Quzwain F. Efek hepatoprotektor ekstrak jintan hitam (Nigella sativa) terhadap kerusakan hepar tikus putih (Rattus norvegicus) jantan galur Sparague Dawley yang diinduksi etanol. Jambi Medical Journal. 2018;6(1).

17. Harianto, Wulandari CE, Hasian T, Widyaningsih TD. Uji efektivitas sifat hepatoprotektor ekstrak bawang lanang pada tikus Wistar jantan yang diinduksi parasetamol. J Pangan dan Agroindustri. 2019;6(4):1-10.

18. Nindy NMT. Uji efektivitas protein biji melinjo (Gnetum gnemon Linn.) terhidrolisis sebagai hepatoprotektor terhadap radikal bebas dalam mencegah peningkatan kadar alkali fosfatase tikus Wistar yang diinduksi CCL4. Respositori UNEJ. Published online 2013. Available from: http://repository.unej.ac.id/handle/1234 56789/71942

19. Hardiningtyas SD, Purwaningsih S, Handharyani E. Aktivitas antioksidan dan efek hepatoprotektif daun bakau api-api putih. J Pengolah Has Perikan Indones. 2014;17(1):80-91. Doi:10.17844/jphpi. v17i1.8140 